\title{
EL PROYECTO DE CREACIÓN DEL OBISPADO DE MONTEVIDEO EN 1809: UN ASPECTO IGNORADO DE LA DEMANDA DE AUTONOMÍA LOCAL
}

\author{
POR \\ FERNANDO AgUERRE CORE ${ }^{1}$ \\ Doctor en Geografía e Historia \\ Universidad de Montevideo
}

RESUMEN

Al igual que ocurriera con la iniciativa de establecer un consulado de comercio en la ciudad o la de aumentar los límites de su jurisdicción, el proyecto de erigir una sede episcopal en Montevideo llegó a la metrópoli en los difíciles tiempos de la guerra de independencia. Cooperaron a la presentación de este proyecto -atrapado en la agonía del régimen español- las fuertes discrepancias de las autoridades de Montevideo con el obispo de Buenos Aires, el Ilmo. Lué y Riega, y la necesidad de corregir la falta de atención espiritual en los pueblos de la campaña oriental. Como singular expresión de la insatisfecha sed de autonomía política de Montevideo, este proyecto aporta datos al análisis de la religiosidad local al tiempo que incursiona en el difícil tema de los límites geográficos de las modernas naciones platenses.

PALABRAS CLAVE: autonomía; sede episcopal; proyecto; discrepancias; atención espiritual; religiosidad; límites.

\section{THE PROJECT OF CREATION OF THE BISHOPRIC OF MONTEVIDEO IN 1809: AN IGNORED ASPECT OF THE DEMAND FOR LOCAL AUTONOMY}

\begin{abstract}
As in the case with the initiative of establishing a trade Consulate in the city or the increase the limits of its jurisdiction, the project of erecting a bishopric in Montevideo became the metropolis in the hard times of the war of independence. They co-operated to the presentation of this project -caught in the throes of the Spanish regime- the strong discrepancies of the authorities of Montevideo with the Bishop of Buenos Aires, Ilmo. Lué y Riega, and the need to correct the lack of spiritual care in the villages of the campaign. As singular expression of the unsatisfied thirst for political autonomy of Montevideo, this project provides data to the analysis of the local religiosity at the same time ventured into the tricky question of the geographical limits of the modern Nations of the Río de la Plata.
\end{abstract}

KEY WORDS: Autonomy; Bishopric; Project; Discrepancies; Spiritual care; Religiosity; Limits.

COMO CITAR ESTE ARTículo / CITATION: Aguerre Core, F. 2017. «El proyecto de creación del obispado de Montevideo en 1809: un aspecto ignorado de la demanda de autonomía local». Hispania Sacra 69, 140: 661-673. doi: 10.3989/hs.2017.041

Recibido/Received 16-12-2015

Aceptado/Accepted 15-01-2016

EL DESARROLLO DEL COMERCIO Y LA TEMPRANA VOCACIÓN AUTONÓMICA DE MONTEVIDEO ${ }^{1}$

La fundación de Montevideo no puede desprenderse de su vinculación con la monarquía borbónica -en particular con el rey Felipe V- a la que quedó asociada aún antes de

${ }^{1}$ faguerre@um.edu.uy / ORCID iD: http://orcid.org/0000-0001 $-8955-6387$ levantarse la ciudad. ${ }^{2}$ Fue este monarca quien se empeñó en defender y poblar el único puerto natural del Plata, que llegaría a ocupar un lugar destacado en el comercio atlántico desde finales del siglo XVIII. La implantación tardía de la ciudad de San Felipe y Santiago de Montevideo en el conjunto del dominio español en el Nuevo Mundo, junto a

2 El primer acto fundacional ocurrió en 1724 por parte del entonces gobernador de Buenos Aires, el mariscal D. Bruno Mauricio de Zabala, en tanto en 1726 se levantó el primer padrón de habitantes. 
la reticencia oficial a la hora de modificar el modelo político preexistente, hicieron que quedara al margen de muchas de las reformas administrativas que se impulsaron por parte de los ministros ilustrados o se viera afectada solamente en forma indirecta. ${ }^{3}$ En 1785 , el gobernador de Montevideo, D. Joaquín del Pino, solicitó de la Corona la concesión a Montevideo del régimen de gobierno-intendencia y que sus límites jurisdiccionales fuesen ampliados a una extensión mayor, desde la Colonia del Sacramento hasta la barra del arroyo Chuy, sobre toda la Banda Oriental del río Uruguay. ${ }^{4}$ No se obtuvo en ese momento una respuesta positiva sobre la promoción de Montevideo al rango de intendencia, ni se obtendría en los años siguientes del dominio español; en cuestión de límites hubo variaciones diversas en el tiempo pero en definitiva todo quedó como estaba.

Sin embargo, a consecuencia de la creciente apertura del comercio, el progreso de la ciudad se hizo evidente en los últimos años del siglo XVIII. Una de las primeras medidas que afectó positivamente la vida de Montevideo fue la prevista en la Real Orden del 9 de agosto de 1776. Se trata de la fundación del Apostadero de Marina con sede en Montevideo. Éste nació con la misión de velar por los intereses de la Corona en el Atlántico sud-occidental, desde la isla de Santa Catalina hasta los canales fueguinos. Dos años después se produjo un hecho determinante para el desarrollo de la ciudad, la aparición del «Reglamento» para el comercio libre de España e Indias, que elevó a Montevideo a la categoría de puerto mayor. ${ }^{5}$ El denominado "comercio libre», a pesar de sus restricciones e impedimentos, otorgó un innegable dinamismo a Montevideo y su campaña.

"A partir de 1778, y sobre todo después de la paz de 1783 con Inglaterra, crece constantemente el tráfico por Montevideo, merced a las condiciones de su puerto y a los sucesivos privilegios que le va otorgando la Corona. En especial se beneficia del tráfico negrero, del comercio de intermediación con Buenos Aires y con el Pacífico, de la venta de tasajo a Cuba, de las disposiciones que autorizan a importar y exportar desde y hacia colonias extranjeras $y$, durante las guerras con Inglaterra, de las negociaciones con neutrales. La instalación de los saladeros orientales -que durante toda la época colonial fueron los únicos existentes en el Plata- incrementan también la actividad económica del territorio». ${ }^{6}$

En los últimos años del siglo XVIII, Montevideo fue objeto de algunos privilegios suplementarios que hicieron progresar sensiblemente a la novel ciudad. Una Real Orden del 2 de junio de 1787 autorizó a la Real Compañía de Filipinas a introducir esclavos negros a través de Montevideo y otros puertos de Chile y Perú; se procedía de manera

3 En particular Montevideo estuvo lejos de verse afectada por las reformas políticas y la nueva organización administrativa del Río de la Plata, distinto fue el caso de la aplicación de la libertad de comercio que favoreció ampliamente a la ciudad.

4 Cfr. Rela 2000: 219. La Banda Oriental tenía como fronteras naturales el río Uruguay por el oeste, el río de la Plata por el sur, y el oceáno Atlántico y los dominios de Portugal por el este y el noreste. Sobre este antiguo territorio en el siglo XIX se constituyó la República Oriental del Uruguay.

5 «Reglamento y Aranceles reales para el comercio libre de España a Indias», 12 de octubre de 1778, en la Imprenta de Pedro Marin, Consultado en: https://archive.org/details/reglamentoyaranc00spai

6 Cfr. Sala de Tourón; De la Torre y Rodríguez 1967: 10. indirecta en barcos adquiridos y armados en Gran Bretaña, con oficiales de nacionalidad inglesa y personal español. ${ }^{7}$ La Real Cédula del 24 de noviembre de 1791 hizo extensiva al Río de la Plata y en concreto a Montevideo la libertad de comercio de negros esclavos, ya sin gravamen alguno. ${ }^{8}$ Los buques que navegaban a cuenta de la Real Compañía de Filipinas introduciendo esclavos en la plaza montevideana, se cargaban de productos de la tierra (cueros, carnes saladas, crines, astas, sebos, grasa y harinas) en el viaje de retorno. Así, se estableció una fluida comunicación entre Montevideo, los puertos del Brasil e Inglaterra.

En este panorama alentador, la creación del Consulado de Comercio en Buenos Aires en 1794 y su política abiertamente contraria a Montevideo supuso, un duro revés. Para reducir ese peligro, los comerciantes locales propusieron la creación de un consulado propio que llegaría recién en los estertores del régimen español en América.

La paz preliminar de Londres en 1801 y el Tratado de Amiens que selló el final de la guerra entre España y Gran Bretaña, aunque efímera, provocaron durante cuatro años no interrumpidos, el ingreso de un gran número de barcos a Montevideo. Una Real Cédula del 22 de abril de 1804 ratificó y amplió en favor de su puerto el privilegio de la libre introducción de esclavos por doce años. ${ }^{9}$ Creció el intercambio comercial con Cuba y los grandes puertos atlánticos de la Unión en la América del Norte. ${ }^{10}$ Dice Falcao Espalter citando a D. Lamas: "Suprimida la Aduana Seca de Córdoba y libertada la navegación del Río de la Plata, éste vino, desde luego, a ser no sólo el centro de todo el comercio del virreinato, sino también de parte del Perú y Chile, beneficiándose principalmente el puerto de Montevideo debido a la superioridad que entonces presentaba para las comunicaciones ultramarinas». ${ }^{11}$

Las invasiones inglesas al Río de la Plata en 1806 y 1807 produjeron un profundo impacto en la vida comercial y en las expectativas de sus habitantes. Montevideo, ocupado por los invasores entre febrero y septiembre de 1807, fue inundado de productos manufacturados a precios muy bajos, mientras toda la producción de cueros salía hacía Inglaterra. Los ingleses respetaron la jurisdicción local y en particular la autonomía religiosa. Durante esos meses no se interrumpió la subordinación eclesiástica al obispo de Buenos Aires pero, en los hechos, hubo decisiones que se adoptaron sin la consulta de rigor al ordinario diocesano.

En 1808, al compás de la invasión napoleónica a España, Montevideo se dio a sí una Junta de Gobierno,

\footnotetext{
Cfr. Azcona 1989.
}

A comienzos del siglo XVIII, los franceses obtuvieron el asiento de negros para introducirlos en el Río de la Plata hasta 1713. Desde ese año hasta 1740, fueron los ingleses los encargados de abastecer de esclavos a esta zona del imperio español. Entre 1740 y 1750 no hubo asiento y los esclavos que llegaron a los dominios españoles por el Río de la Plata provenían del contrabando portugués en la Colonia del Sacramento. En 1750 se ensaya traer negros desde África en navíos de asiento con armadores españoles. En 1755 el derecho es otorgado a Nicolás de Aizpurúa cuyos barcos hacían escala en Guinea antes de dirigirse a Montevideo. En 1761 el sistema fracasó y hasta el año 1781 no hubo otra entrada de negros en el Río de la Plata sino aquellos que por contrabando llegaban desde la colonia portuguesa. Cfr. Azcona 1989: 81-82.

9 Cfr. Rela 2000: 269.

10 Cfr. Falcao Espalter: 24-25.

11 Ibídem: 26. 
fundada en la irrenunciable potestad de los pueblos de autogobernarse en ausencia del legítimo monarca. Se cortaron todas las relaciones de dependencia con la capital virreinal y Montevideo declaró su fidelidad a la Corona sin intermediación alguna. En el gobierno espiritual, el cuidado de los fieles fue confiado al clero secular y regular nativo, que era partidario de la Junta de Gobierno.

La imagen que por aquellos años ofrecía Montevideo a los viajeros que llegaban hasta su puerto aparece en un texto de 1808, del francés Julien Mellet y en los grabados de 1807 realizados por Edward Orme y P. Guichenet, arribados con la expedición británica. Explicando las perspectivas que ofrecía la ciudad, decía Mellet: «Está muy bien fortificada, tiene un puerto muy seguro a 22 leguas del mar... Las calles son anchas y bien rectas, las casas edificadas con ladrillos y coronadas de terrazas como en Maldonado, facilitan la comunicación en la vecindad y sirven para distraer la vista; las iglesias son hermosas y bien decoradas, los mercados están bien aprovisionados de todo lo necesario... En esta ciudad reina la abundancia». ${ }^{12}$ En una de las vistas de Montevideo aparece su bahía cubierta de grandes navíos cargados de mercaderías; en otra, destaca la imponente silueta de la entonces nueva Iglesia Matriz, consagrada por el Ilmo. Lué el 21 de octubre de $1804 .^{13}$

Es en este contexto, que en 1809 aparece el proyecto de constituir en la ciudad un obispado independiente del de Buenos Aires. La prosperidad material de la ciudad favorecida por las reformas económicas del período final del siglo XVIII y la circunstancia histórica del gobierno autonómico de la ciudad allanaron el camino que permitía alentar una independencia eclesiástica. No es posible comprender esta propuesta de la Junta de Gobierno de Montevideo, si se desconoce la escalada autonómica de la ciudad confiada en su progreso material y consciente de las dificultades que ofrecía su cercanía a la capital virreinal. El presente estudio apunta al análisis de ese proyecto que sucumbiría junto a la ciudad fiel a la monarquía, en junio de 1814 , luego de que el ejército de Buenos Aires irrumpiese como un vendaval sobre Montevideo, sofocando temporalmente cualquier tentativa autonómica. El contexto histórico de este análisis no sobrepasa -entonces- al período del dominio español en Montevideo, puesto que el proyecto había perdido viabilidad aún antes del triunfo de las fuerzas patriotas.

\section{LA VISITA PASTORAL DEL OBISPO LUÉ Y EL ESCRITO DEL SÍNDICO PROCURADOR DE MONTEVIDEO}

En los antecedentes del proyecto de obispado está el escrito presentado por el síndico procurador del Cabildo de Montevideo, D. Bernardo Suárez del Rondelo, en el que no

\footnotetext{
12 Mellet 1988: 18.
}

13 Grabado 1: A view of the Town, Citadel and Mount of Montevideo in the Río de la Plata taken during the late Seige; Shewing the approaches of the British Army under the command of Brigadier General Sir Sam.I. Auchmuty...by their obliged and obedient humble Servant P. Guichenet (Aqua tinted by I. Jeakes). Grabado 2: Asalto de Montevideo, 3 de febrero de 1807, dedicado con autorización al B. General Sir Samuel Auchmuty y a los oficiales que tomaron parte en tan gallardo como memorable ataque, por Edward Orme (Plan of the City and March of the Troops), Bond Street London. sale favorecido el IImo. D. Benitó Lué y Riega. ${ }^{14}$ Este singular prelado, el último de los obispos del Río de la Plata durante el dominio español, tomó la iniciativa de realizar una visita pastoral a Montevideo y a toda la Banda Oriental. Con esa decisión se embarcó en Buenos Aires el 13 de mayo de 1804. La anterior inspección de la ciudad y su territorio había sido practicada por el Ilmo. D. Manuel A. de la Torre entre fines de 1772 y los primeros meses de 1773. Otro prelado, Fr. Sebastián de Malvar y Pinto, «había caminado» desde Montevideo a Santo Domingo Soriano, de paso hacia Buenos Aires en 1778. No pudo, entonces, reconocer la mayoría de los pueblos dispersos en aquel territorio. Habían pasado treinta y un años desde la visita del obispo Torre y veintiséis de la del obispo Malvar. Tanto los vecinos de la ciudad como los de la campaña oriental esperaban gozosos la llegada del nuevo prelado. La visita comenzó por Santo Domingo Soriano -junto al río Uruguay- y fue avanzando por pueblos y capillas, de oeste a este, hasta llegar a la fortaleza de Santa Teresa en el límite de los dominios de España con Portugal. El 16 de septiembre de aquel año, ya de regreso, bendijo el obispo la nueva iglesia de San Carlos en la villa homónima y luego de pasar por San Fernando de Maldonado llegó a Montevideo a comienzos del mes de octubre de 1804. En la capital de la gobernación se detuvo para consagrar el nuevo templo mayor de la ciudad. El 15 de diciembre ya estaba el prelado de regreso en Buenos Aires.

Recién cuatros años después de finalizada esta visita, el 7 de febrero de 1809, Suárez del Rondelo -hacendado en Canelones y en el Cerro Largo- se dirigió a la Junta de Gobierno de Montevideo, a fin de descubrir algunos detalles que la hacían singular y ejemplificadora. ${ }^{15}$ La finalidad del escrito era dar a conocer, dice el síndico procurador, "los excesos que he advertido en el Sr. Obispo de esta Diócesis a fin de que sobre ellos informe a S.M. lo que tenga por justo». ${ }^{16}$ Ha de tenerse en cuenta que Bernardo Suárez, asturiano al igual que el prelado, dirigió su informe a la junta un mes después de haber jurado su cargo y lo hizo presuntamente llevado de su obligación de mirar por el bien común de los vecinos de Montevideo y su jurisdicción. No se oculta, empero, que las circunstancias del momento histórico favorecían el diligenciamiento de los puntos de la propuesta que, posiblemente, contara desde antes con el apoyo de los miembros de aquel consejo rebelde, embanderado como estaba en la lucha por la autonomía bajo el pretexto de la invasión napoleónica y la supuesta connivencia del virrey Liniers con Bonaparte.

14 Don Benito Antonio Gregorio de Lué y Riega nació el 12 de marzo de 1753 en el puerto de Lastres, perteneciente al municipio de Colunga y diócesis de Oviedo, en el principado de Asturias; se había graduado de bachiller, licenciado y doctor en las aulas conventuales de los Dominicos de Ávila en 1791 y al momento de ser designado por la Cámara de Indias para la diócesis del Río de la Plata era deán de la catedral de Lugo. El rey Carlos IV lo presentó al solio pontificio el 21 de febrero de 1802. Llegó a Montevideo el 30 de marzo de 1803 y a Buenos Aires el 22 de abril. Fue consagrado obispo en Córdoba el 29 de mayo de 1803 de manos del obispo diocesano, Ilmo. D. Ángel Mariano Moscoso. Cfr. Bruno 1971: 41-43.

15 Francisco Bernardo Suárez del Rondelo y López de Avilés nació el 10 de julio de 1749 en el caserío de Ferradal, Concejo de Castropol, en la Provincia de Oviedo.

16 AGI Buenos Aires 609, Bernardo Suárez al Presidente y Vocales de la Junta de Gobierno, Montevideo 7 de febrero de 1809. 
La ruptura de Montevideo con Buenos Aires, a raíz de la constitución de la Junta de Gobierno en la primera ciudad, hacía impracticable que cualquier iniciativa llegase a los órganos de control en la capital virreinal. Por tal razón, la petición se dirigió directamente a las autoridades que la metrópoli se había dado en la emergencia de la guerra de independencia. Uno de los primeros párrafos del oficio escrito por el síndico procurador desvela la razón fundamental de aquel severo examen de la visita pastoral. Dice Suárez, que el prelado «andubo o corrió la mayor parte de esta campaña de un modo tan gravoso a sus habitantes que faltaría yo a una de mis primeras obligaciones si no lo recordase a V.S.S. para su remedio y precaver q.e. en adelante se repitan semejantes abusos $»{ }^{17}$

El obispo Lué en su viaje se había servido de un coche para el transporte de sí mismo y de sus acompañantes y varias "carretillas» para el equipaje de los viajeros; sin embargo, "no costeaba ni los animales necesarios para su tiro ni los peones o carretilleros q.e. havían de conducir los carruajes». ${ }^{18}$ La situación debían remediarla los curas párrocos o sus tenientes, que eran quienes debían proporcionar los peones y caballos necesarios para asegurar la continuación del viaje. Con estas palabras lo explicaba Suárez: los curas «que por lo regular son pobres sin más ovenciones que las precisas para su congrua sustentación» se veían obligados a suplicar a sus feligreses auxilio y colaboración «para no incurrir en la desgracia de su obispo». ${ }^{19}$ La queja era más sensible puesto que las «marchas violentas» del señor obispo demandaban el cambio continuo de las cabalgaduras. ${ }^{20}$ Esta forma de proceder ofuscaba al síndico procurador, puesto que el prelado disfrutaba de una renta fija que no debía bajar -en su opinión- «de veinticinco mil pesos, la cual sale del sudor de aquellos mismos a quienes venía a visitar $»{ }^{21}$ Las quejas se referían también al trato que el Ilmo. Lué había dispensado a sus feligreses. La visita no lograba «consolar a las ovejas de su rebaño», sino que -en opinión del denunciantelas llenaba «de amargura y desconsuelo, sugetándolos a una nueva contribución», porque aquellos vecinos debían renunciar a la utilidad de los caballos que estaban destinados al trabajo en el campo y también a los peones que pasaban al servicio del ilustre visitante. Todo aquel esfuerzo -en el razonamiento que hacía Suárez- tenía como único objeto que «el Sr. Obispo hiciese su visita sin tocar un maravedí de su pingue renta». ${ }^{22}$ La conclusión es sorprendentemente dura y parece explotar la impresión poco amable que habría dejado el Ilmo. Lué entre los vecinos de Montevideo y la campaña. Pero la visión negativa sobre el prelado y su actuación no era exclusiva de Montevideo; las mayores

17 AGI Buenos Aires 609, Bernardo Suárez al Presidente y Vocales de la Junta de Gobierno, Montevideo 7 de febrero de 1809.

18 AGI Buenos Aires 609, Bernardo Suárez al Presidente y Vocales de la Junta de Gobierno, Montevideo 7 de febrero de 1809.

19 AGI Buenos Aires 609, Bernardo Suárez al Presidente y Vocales de la Junta de Gobierno, Montevideo 7 de febrero de 1809. A estos gastos debía agregarse, según Suárez, todo lo que fuese «necesario para su alimento y regalo».

20 AGI Buenos Aires 609, Bernardo Suárez al Presidente y Vocales de la Junta de Gobierno, Montevideo 7 de febrero de 1809.

21 AGI Buenos Aires 609, Bernardo Suárez al Presidente y Vocales de la Junta de Gobierno, Montevideo 7 de febrero de 1809.

22 AGI Buenos Aires 609, Bernardo Suárez al Presidente y Vocales de la Junta de Gobierno, Montevideo 7 de febrero de 1809. críticas que recaían sobre el obispo provenían del Cabildo eclesiástico de la catedral bonaerense. ${ }^{23}$ En Buenos Aires, el prelado tenía tantos y más enemigos que en Montevideo, aunque tampoco le faltaban defensores. Los fiscales Villota y Caspe alabaron su generosidad y no dejaron de mencionar los "repetidos donativos» hechos por el prelado "en auxilio de los extraordinarios gastos de la guerra», en tiempos de la invasión de las tropas británicas. Asimismo, se señalaba que el Ilmo. Lué había acudido prontamente «en socorro de las viudas y huérfanos». ${ }^{24}$ El nuevo virrey, D. Santiago de Liniers, también intervino en defensa del obispo de Buenos Aires. ${ }^{25}$

D. Benito Lué había sido oficial del ejército antes de abrazar la carrera eclesiástica y no se pueden desconocer sus dotes de mando y organización. ${ }^{26}$ La visita pastoral no dejó de reconocer rincón alguno de la vasta campaña oriental con sus ciudades y pueblos. Sin menospreciar estas calidades del prelado, Suárez argumentaba que el obispo padecía una preocupación excesiva por el ahorro, tratándose -claro está- de sus bienes propios. El año 1804 fue pobre en cantidad de trigo cosechado: así, se cobró «la fanega hasta veinte pesos fuertes" y -en cambio- había sido "copioso de \|luvias», lo que provocó grandes dificultades para andar por los campos y en particular para los hacendados que debían "conducir a esta ciudad el fruto de sus haciendas». ${ }^{27} \mathrm{~A}$ pesar de aquella realidad hostil, el buen prelado hacía "andar su coche y las carretillas de su equipaje quatro leguas por hora», según lo había podido verificar otro vecino de Montevideo, Manuel Durán, quien había padecido las consecuencias de la visita en su propia hacienda. Según afirmaba el síndico procurador, el prelado exigía de parte de su fieles que lo "reciviesen" y tratasen "con esplendidez» y si así no sucedía le era difícil disimular la irritación. De esta manera tan poco paternal había "corrido» aquella visita y en todos los lugares donde estuvo «se dejó servir con franqueza de los curas y de los que no lo eran, y en todas partes dejó mucho q.e. ablar y maldecir ». ${ }^{28}$ En Montevideo fue recibido por el clero a las puertas de la Iglesia Matriz y desde allí conducido a la casa que se le había preparado para su estancia en la ciudad. ${ }^{29}$ Se conoce por el escrito de Suárez que en ese lugar volvió a protagonizar una doble

23 Como testimonia el P. C. Bruno, en carta dirigida por el Cabildo Eclesiástico de Buenos Aires al Rey, con fecha del 10 de febrero de 1806, se acusaba al prelado de llevar en su visita pastoral «hasta catorce personas de servicio y un tren de vehículos tirados por cincuenta, cien y más caballos, todo a costa de los respectivos curas; a quienes, por otra parte, exigió sus cuartas episcopales sin perdonar la pobreza de muchos de ellos», en Bruno 1971: 49.

24 Ibídem: 121.

25 Ibídem: 122.

26 Egaña 1966: 717

27 AGI Buenos Aires 609, Bernardo Suárez al Presidente y Vocales de la Junta de Gobierno, Montevideo 7 de febrero de 1809.

28 AGI Buenos Aires 609, Bernardo Suárez al Presidente y Vocales de la Junta de Gobierno, Montevideo 7 de febrero de 1809.

${ }_{29}$ Una denuncia que no consta en el informe de Suárez desnuda la conducta del Ilmo. Lué en Montevideo a juicio de sus críticos, que eran muchos. Según testimonio del comisario del Santo Oficio en Buenos Aires, D. Fabián de Aldao, en carta a su colega de Corrientes: «El Obispo viene ya de regreso de la visita Es el más desaforado loco que nos ha venido del otro lado de los mares. Al cura de Montevideo, no obstante que posaba en su casa, que le daba de comer y lo ha obsequiado completamente los treinta y siete días que estuvo allí, por las desavenencias que tiene con el sacristán Echeverría le dijo que lo había de secar en una cárcel», en Bruno 1971: 50. 
descortesía, con el mariscal de campo D. Miguel de Texada y con el cuerpo de oficiales a quienes recibió sentado en su trono. Ni uno ni otros fueron invitados a tomar asiento en su presencia; ni siquiera respetó la edad avanzada de Tejada. En opinión de su implacable crítico, de los sermones del señor obispo en los días en los que administró el sacramento de la confirmación, no se advirtieron sino pobres resultados. Se preguntaba el síndico procurador: "¿qué fruto podía el Prelado sacar de un auditorio que lo oía con desafecto (por no decir con odio) y solo por la necesidad de q.e. reciviesen la confirmación los individuos de sus familias, que no habían recibido ese sacramento?». Al término de la visita, el Ilmo. Lué abandonó la Banda Oriental con la alegría de todos los vecinos: "hasta las matronas más devotas dieron gracias a Dios», afirmaba Suárez. Como colofón, cerraba aquel pasaje de su informe, agregando que el obispo una vez regresado a Buenos Aires: «no cesó nunca de incomodar a este Pueblo en quanto pudo". ${ }^{30}$ Las molestias que, en opinión del síndico procurador, continuó provocando el obispo de Buenos Aires entre los habitantes de Montevideo, se relacionaban con su celo recaudador y la desconfianza que demostraba hacia los fieles y sus pastores.

\section{LA INVASIÓN INGLESA A MONTEVIDEO Y EL PRIMER ENSAYO DE} AUTONOMÍA ECLESIÁSTICA

En 1806 Buenos Aires fue invadida por una escuadra inglesa que capturó el tesoro del Alto Perú y se adueñó de la ciudad. En conocimiento de este suceso, el gobierno y las fuerzas vivas de Montevideo organizaron y proveyeron una fuerza militar que bajo la dirección del futuro virrey, el capitán de navío D. Santiago de Liniers, se dirigió a la capital virreinal. Allí, con el concurso de las tropas locales, el ejército reconquistador alcanzó el triunfo. Los invasores fueron expulsados del territorio pero se mantuvieron en aguas del Río de la Plata. La indignación de los vecinos de Montevideo con su obispo aumentó al conocerse que, «al ocurrir la toma de la capital (Buenos Aires) por Beresford» en 1806, «junto con la nota laudatoria que los prelados regulares enviaron al triunfador, el Ilmo. Lue aprovechó la coyuntura que le ofrecía el día de Santiago, 25 de julio, para loar la conducta de los ingleses». ${ }^{31}$ Esta reacción frente al invasor-como dice Egaña- escandalizó al Cabildo Eclesiástico de Buenos Aires, que no tardó en presentar una denuncia al monarca.

Montevideo no evitaría constituirse en el objetivo de una segunda arremetida británica al año siguiente. En aquel difícil escenario, el comercio tradicional se paralizó mientras la población esperaba con angustia creciente el ataque invasor por mar y tierra. Éste llegó a comienzos del año 1807. Un poco antes de la caída de Montevideo en manos de las armas de S. M. B., el Ilmo. Lué envió un delegado a la ciudad y su campaña, para que los curas remitiesen lo adeudado "de quartas» y lo que la generosidad de los fieles pudiese adelantar en metálico antes de que se concretara la invasión. ${ }^{32}$ La medida causó una gran indignación entre los habitantes de

30 AGI Buenos Aires 609, Bernardo Suárez al Presidente y Vocales de la Junta de Gobierno, Montevideo 7 de febrero de 1809.

31 Egaña 1966: 719.

32 No especifica Suárez a qué «quartas» se refiere, si a las cuartas de los diezmos o a las cuartas canónicas y funerarias que eran «derechos útiles» que percibía el obispo por ley diocesana, en Andrés 1848: 240.
Montevideo y los pueblos inmediatos. No obstante, muchos vecinos contribuyeron en la medida de sus posibilidades a atender las necesidades del culto y las obras de misericordia del obispado a las que iban destinadas las limosnas.

Pese a su heroica resistencia, Montevideo terminó cayendo en poder de los ingleses en la mañana del 3 de febrero de 1807. En la defensa murieron cientos de soldados improvisados, entre otros el fundador del Hospital de la Caridad, D. Francisco Antonio Maciel. Fueron muchos los funcionarios del virreinato que hicieron llegar el pésame a la ciudad; muy por el contrario, el obispo de Buenos Aires no hizo manifestación alguna de pesar por la noticia. Por contraste, el arzobispo metropolitano de La Plata -en el Alto Perú- de quien el obispo de Buenos Aires era sufragáneo, el Ilmo. D. Benito de Moxó y Francolí, celebró en su catedral solemnes exequias fúnebres por los caídos en Montevideo y escribió a los sobrevivientes honrando el nombre de los valientes.

Una vez establecidos los ingleses en Montevideo y curadas la heridas del duro asedio, la vida de la ciudad fue volviendo a sus cauces normales; el único cambio visible era que ya no se obedecía a las autoridades de Buenos Aires sino al Comandante británico, quien únicamente se reservaba "los crímenes que dirijan a inquietar el Gobierno de S.M.B». ${ }^{33} \mathrm{El}$ artículo 5ㅇ de la Proclama de los ingleses establecía que "los magistrados, hasta que otras órdenes se den, continuarán en el ejercicio libre de sus diferentes empleos en todo lo perteneciente a lo político de la ciudad y su jurisdicción, bajo aquellas alteraciones o reformas que el General Comandante en Jefe hallare por conveniente». ${ }^{34}$ A los invasores -que venían a encontrar posibles mercados para su producción y aumentar el desarrollo mercantilinteresaba fundamentalmente conseguir las mejores condiciones de funcionamiento de aquel puerto, principal en el Atlántico sur; no podían en esto sino coincidir con los intereses de los comerciantes montevideanos. Así es que no ha de extrañar el rápido entendimiento de unos con otros y que a ese tiempo pertenezcan algunos proyectos de obras que se fueron concretando cuando ya los ingleses habían abandonado la ciudad y se había restablecido la fidelidad a la corona de España.

No ha de pensarse exclusivamente en los beneficios económicos que dejó aquella ocupación, sino también en la demostración de tolerancia y aún en la difusión de ideas que alivianaron el natural rechazo que los invasores despertaron primariamente entre los vecinos. El gobierno inglés apareció incluso como protector de la religión frente a la impiedad del aliado histórico de España, que era la Francia napoleónica. Desde la editorial del primer número del periódico bilingüe "The Southern Star» o "La Estrella del Sur», que se imprimía en Montevideo gracias a una prensa traída por los ingleses, se preguntaba a los buenos españoles por el desmayo de la península: «¿Suplicaréis el amparo de aquella nación ambiciosa y ladrona (Francia) que ha consumido vuestras riquezas, que ha robado vuestras iglesias e insulta vuestra religión santísima? ¿Qué ha trastornado vuestros altares, que ha quebrantado

\footnotetext{
33 Pérez Castellano 1968: 118-119.

34 Ibídem: 118.
} 
sacrílegamente todas las leyes humanas y divinas».. ${ }^{35} \mathrm{Es}$ cierto que Francia había sido -y volvería a ser- una aliada de la España borbónica pero, en aquel momento, la actitud beligerante del emperador fue presentada por los agentes de Inglaterra como un vendaval de latrocinio y burla de todo lo que los españoles veneraban con mayor pasión. No se puede afirmar que Gran Bretaña haya obtenido la simpatía de los montevideanos; sin duda despertó la aprobación de algunos vecinos -se realizaron matrimonios mixtos de oficiales ingleses con jovencitas del lugar-, pero es innegable que la ocupación no alteró la fe sencilla ni las creencias religiosas de los vecinos. Por el contrario, los extranjeros introdujeron un profundo sentimiento de tolerancia. En la Proclama de los generales ingleses, como la llama el P. Pérez Castellano, fechada el mismo 3 de febrero de 1807, en el artículo 3으, establecían los invasores: «Los habitantes de dicha ciudad [Montevideo] y su jurisdicción podrán libremente ejercer la Religión Católica Romana, seguros de que se tendrá todo el respeto a los ministros del Evangelio, conservándose ellos en los límites de sus sagradas funciones, y se porten como verdaderos vasallos sin alucinar al pueblo contra el Gobierno de S.M.B.». ${ }^{36}$

Al igual que ocurriera en los otros órdenes de la sociedad local, en el eclesiástico no se experimentó afrenta alguna por parte del ejército invasor; de hecho, no se registraron denuncias en todo ese tiempo. Aún más, los representantes británicos supieron disimular la impertinencia de algún clérigo empecinado en su oposición, cuando era de público conocimiento que las autoridades de la ciudad se habían rendido honrosamente a la fuerza invasora. Así lo relata el Pbro. José Manuel Pérez Castellano en sus «Escritos». Dice aquel sabio sacerdote que, convocado -el 6 de febrero de 1807- el clero de la ciudad en la sala consistorial para prestar juramento de fidelidad al gobierno de S. M. B, el Vicario y Rector de la Iglesia Matriz de Montevideo, el Pbro. Juan J. Ortiz -oriundo de Buenos Aires- respondió al gobernador Sir Gore Brown que no podía prestar aquel juramento sin el consentimiento del obispo domiciliado en la capital virreinal. A modo de pretexto invocó la existencia de ciertas bulas pontificias que impedían la conducta esperada. El gobernador le expuso la imposibilidad de obtener ese consentimiento pero, a pesar de esas palabras conciliadoras, el Dr. Ortiz no modificó su posición. Frente a esta actitud, el P. Pérez Castellano -hijo de Montevideo- no dudó en adelantar su disposición a realizar aquel juramento en atención a las circunstancias y sabiendo los presentes cuál había sido su conducta durante el asedio y su lealtad al rey natural. ${ }^{37}$

35 The Southern Star (La Estrella del Sur), Saturday May 23, 1807, No. 1 (facsímil): 1., Montevideo: Instituto Histórico y Geográfico del Uruguay - Barreiro y Ramos.

36 Pérez Castellano 1968:118.

37 El relato de Pérez Castellano es ilustrativo de las diferencias entre el clero local y el Vicario que venía de Buenos Aires: «Viendo yo que la cosa tiraba muy a lo largo, y causándome vergüenza que creyesen los que oían la cuestión (que eran muchos) que todos los del clero adoptábamos las objeciones del vicario como si fueran de una gran fuerza, me resolví a decir que yo no tenía dificultad alguna en jurar que cumpliría lo que consideraba ser de mi obligación; que yo por mi parte había contribuido todo lo que me fue posible a fin que la Plaza se defendiese $y$ conservase para nuestro Rey y Señor natural; pero que habiendo sido vanos nuestros esfuerzos, y hallándome yo en la necesidad de vivir en
Cuando Montevideo regresó al dominio de la corona española en septiembre de $1807^{38}$, una vez evacuada la ciudad por las tropas británicas, el llmo. Lué se preocupó de anunciar el envío a la Banda Oriental de varios «misioneros evangélicos que con su predica.n. arrancasen la mala semilla q.e. se havia propagado y se consiguiese la reforma de las costumbres corrompidas". ${ }^{39}$ Este edicto del prelado, que en otras circunstancias se hubiese recibido como efecto de su celo pastoral, fue tenido como un insulto que afligió todavía más al vecindario montevideano. Como explicaba el síndico procurador, el obispo había supuesto que:

...los Ingleses entraron a la Plaza dogmatizando sus errores, separándonos de nuestra Religión Catolica e inspirando el libertinaje y unas costumbres licenciosas, con cuio supuesto se les hacía una injuria palpable, porq.e. ni los que mandaban, ni las tropas, ni los comerciantes, se separaron jamás de una honrada y circunspecta comportación; no atendían a más que a su propia seguridad y defensa, a su comercio, y a la tranquilidad del Pueblo, a quien dejaron el libre exercicio de la Religión Católica sin hacer cosa alguna que manifestase desprecio, ni de la religión, ni de los que la profesaban. Esta verdad la arranca del corazón a la pluma la Justicia: la ha confesado siempre este Pueblo y muchos de sus vecinos dieron por escrito testimonio de ella quando los Ingleses se despedían y quando eran aún nuestros enemigos. ${ }^{40}$

Esta evidencia de primera mano pone de manifiesto la actitud respetuosa de los ingleses en relación a las demostraciones de la fe y las costumbres de los habitantes de la ciudad. El cabildo se vio en la obligación de responder al prelado que no había peligro alguno de corrupción o desvío de la fe después de la ocupación británica. En consecuencia, los misioneros del Ilmo. Lué nunca llegaron a Montevideo. Suárez da a entender en su informe que el obispo conoció los sentimientos de los habitantes ante aquel edicto y se arrepintió de la medida anunciada.

Regresando al informe, en él no solo se señala la improcedencia del IImo. Lue sino que de su lectura se advierte un velado entusiasmo por ciertas ventajas comparativas que la ocupación británica habría permitido obtener en tan corto tiempo. La experiencia de la autonomía tutelada bajo la ocupación de las fuerzas de S. M. B. no pasó desapercibida para muchos ricos comerciantes y hacendados de la Banda Oriental: ese era el caso de Suárez del Rondelo, pero no fue el único.

Una última curiosidad relacionada con aquel prelado. Cuando Bernardo Suárez en 1809 cierra su informe con la

ella, porque en ella tenía mis posesiones y toda mi subsistencia, no me quedaba otro recurso que el de sujetarme y subordinarme al nuevo gobierno, y vivir en él tranquilo», en Pérez Castellano 1968: 129.

38 El 28 de junio de 1807 un poderoso ejército británico al mando del general John Whitelocke desembarcó cerca de Buenos Aires para intentar una segunda captura. Sin embargo, esta vez la capital virreinal se defendió calle a calle y los invasores fueron rechazados. El 7 de julio el general inglés debió aceptar la capitulación propuesta por Liniers, a la cual por exigencia del alcalde D. Martín de Álzaga se añadió que en un plazo de dos meses las fuerzas británicas de ocupación deberían abandonar también Montevideo. Esta medida se terminó ejecutando más tarde, el 9 de septiembre de 1807.

39 The Southern Star (La Estrella del Sur), Saturday May 23, 1807, No. 1 (facsímil): 1. Montevideo: Instituto Histórico y Geográfico del Uruguay - Barreiro y Ramos.

40 AGI Buenos Aires 609, Bernardo Suárez al Presidente y Vocales de la Junta de Gobierno, Montevideo 7 de febrero de 1809. 
descripción de las «pequeñeces y miserias» del obispo Lué, dice que éste había sido enviado al Río de la Plata por «el anti-soberano Godoy». ${ }^{41} \mathrm{Si}$ bien no ha de llamar la atención el calificativo aplicado al príncipe de la Paz, ya por aquel entonces en el destierro junto al destronado monarca y su esposa; no deja de sorprender tan categórico juicio en labios del regidor de una ciudad tan alejada del centro del poder. Una pista posible que explica el apelativo arrojado sobre el ministro se halla en la prensa montevideana de 1807. En efecto, "La Estrella del Sur» hizo una fuerte campaña en contra de Godoy. El impopular "favorito» era apostrofado con estas expresiones: "un ministro infame, el instrumento y criatura de un tirano extraño y el traidor de su patria, la España». ${ }^{42}$ La intención del responsable de esa publicación -que era español aunque al servicio de Inglaterra- había sido asociar a Godoy con el aborrecido Napoleón y por contraste destacar las ventajas que ofrecía el modelo político de la Gran Bretaña. El propósito de Suárez no es tan claro en este punto, pero -al menos- su intención parece ser identificar al obispo de Buenos Aires con Godoy, quien era considerado amigo de los enemigos de España. Si algo faltaba para convertir al obispo Lué en el blanco de todos los odios era acusarlo de ser «hechura» de Godoy.

\section{LA JUNTA DE GOBIERNO Y EL PROYECTO DE CREACIÓN DEL OBIS- PADO DE MONTEVIDEO}

El 11 de febrero de 1809, es decir, cuatro días después de la fecha que lleva el escrito de Bernardo Suárez, la Junta de Gobierno de Montevideo se dirigió al Rey a fin de hacer presente las quejas sobre la conducta del Ilmo. Lué. Sobre esta trama posiblemente exagerada se entretejía la verdadera intención de la junta, pedir el establecimiento de un obispado para la ciudad. La solicitud iba acompañada de la copia del informe de Suárez. La decisión de elevar esta solicitud fue aprobada con los votos del presidente, el gobernador Francisco Javier de Elío, y de los vocales Parodi, Berro, Errazquín y Pérez Castellano. ${ }^{43}$

El informe original de Suárez se cerraba con tres peticiones que iban dirigidas al monarca y que la Junta hizo propias. La primera decía así:

que los obispos en adelante hagan su visita no a costa de los curas y mucho menos de los Pueblos por donde transitan, sino a costa de su renta en atención a que esta es suficiente y muy sobrada para este gasto y para los demás correspondientes al decoro y dignidad de sus personas, mandando al mismo tiempo que los gobernadores y cabildos tengan cuidado y no omitan jamás informar a S.M. de los abusos que adviertan sobre esta materia. ${ }^{44}$

Esta demanda recogía un sentimiento extendido entre los vecinos de la ciudad que era contrario al IImo. Lué; sin embargo, la intención no se limitaba a aquel único prelado.

41 AGI Buenos Aires 609, Bernardo Suárez al Presidente y Vocales de la Junta de Gobierno, Montevideo 7 de febrero de 1809.

42 The Southern Star (La Estrella del Sur), Saturday May 23, 1807, No. 1 (facsímil): 1. Montevideo: Instituto Histórico y Geográfico del Uruguay - Barreiro y Ramos.

43 AGI Buenos Aires 609, La Junta de Gobierno de Montevideo, Montevideo 11 de febrero de 1809.

${ }_{44}$ AGI Buenos Aires 609, Bernardo Suárez al Presidente y Vocales de la Junta de Gobierno, Montevideo 7 de febrero de 1809.
Muy por el contrario, la solicitud se hacía en atención a los tiempos venideros, con el objeto de instruir a gobernadores y cabildos para que estuviesen alerta sobre situaciones similares que se podían presentar y prevenir la conducta de quien intentase apartase de los rectos criterios. En esta petición parece percibirse una nueva postura que algunos obispos españoles venían denunciando desde unos años antes. $^{45}$ La formulación postula un quiebre en el «nexo jurídico» y por tanto en el "político», entre el "poder temporal de la Iglesia y los derechos del ciudadano", tal como comenzaba a entenderse por aquellos años entre liberales y constitucionalistas laicos. ${ }^{46}$ No se quiere desorbitar el contenido de esta primera solicitud de Suárez pero, en definitiva, la intención parece ser poner a cubierto a los vecinos de un territorio o de una ciudad de lo que podrían ser los requerimientos temporales de los eclesiásticos. En el giro «mucho menos de los Pueblos» parece advertirse la aspiración de que fuese aliviado -únicamente en materia temporal- el vínculo natural entre el obispo y los súbditos cristianos, tal como se había establecido en la Edad Media. El síndico procurador de Montevideo alegaba en favor de su postura, en el caso concreto: «el carácter amargo, duro e inrregular (sic) de nro. Prelado cuia dignidad respeto como christiano católico q.e. soy». La declaración final de Suárez dejaba a salvo su condición de católico y el acatamiento a la potestad del ordinario diocesano que no discutía.

En la segunda proposición, Bernardo Suárez va derechamente a solicitar el alejamiento del obispo Lué de su diócesis:

que S.M. se digne remover de este obispado al IIImo. Sr. D. Benito Lué y Riestra (sic), porque su permanencia en él ya no puede ser de utilidad ninguna ni temporal ni espiritual a esta Provincia, hallándose en ella generalmente mal visto, y sin esperanza de q.e. los súbditos puedan acordarse jamás con un Prelado con quien están constantemente ofendidos desde los principios de su obispado. ${ }^{47}$

No sorprende esta segunda propuesta tampoco: en las crónicas de la América española hubo peticiones similares y aún más encendidas, que llegaron hasta la violencia de expulsar al obispo de su sede. El Ilmo. Lué no era querido tampoco en Buenos Aires -como ya se ha visto-y el cabildo eclesiástico de la capital virreinal había solicitado al rey su remoción en distintas oportunidades. ${ }^{48}$

La tercera propuesta de Suárez es la que más interesa en este estudio y es la que pasó a constituirse en solicitud formal de la Junta de Gobierno de Montevideo.

45 Lo que los obispos defendían era «la supervivencia casi inalterada... de esquemas de pensamiento provenientes de la Edad Media y de la tradición del agustinismo político, con la correspondiente interpretación de los principios del primado de los spiritualia sobre los temporalia, según la cual la potestas de los príncipes temporales debía estar al servicio de la auctoritas del poder espiritual», en Rhonheimer 2009: 86

46 Ídem.

47 AGI Buenos Aires 609, Bernardo Suárez al Presidente y Vocales de la Junta de Gobierno, Montevideo 7 de febrero de 1809.

48 En 1810, al estallar la revolución de mayo, el obispo de Buenos Aires mantuvo distancia de los cambios y de las personas si bien acató la nueva autoridad. Murió dos años después, en circunstancias poco claras, en la localidad de San Fernando (Buenos Aires) en marzo de 1812. El deceso se produjo -posiblemente- como efecto de un veneno que habría ingerido en ocasión de una celebración en su honor. No puede decirse que este prelado no tuviera enemigos en una y otra orilla del Plata. 
Se trata de la partición en dos del obispado de Buenos Aires y la creación de otra diócesis con sede en Montevideo. El proyecto del nuevo obispado no se sustentaba única ni principalmente en los errores que habría cometido el obispo Lué. Muy por el contrario, esa división era presentada como el fruto de aspiraciones compartidas por los vecinos más destacados de la ciudad que, llegado el tiempo oportuno, lo elevaban a la más alta consideración de la monarquía. Las circunstancias locales ya se han relatado y en opinión de los miembros de la Junta, los hechos públicos ocurridos en la península y los temores que despertaba la actitud de Buenos Aires lo hacían aconsejable.

Para los firmantes de aquella petición, el proyecto del obispado era la oportunidad de hacer valer y cumplir el derecho que tenían los pueblos particulares a darse autoridades propias, en este caso eclesiásticas. ${ }^{49}$ Pero esta deseada autonomía también venía a vengar los numerosos y antiguos agravios -como se decía- llegados desde Buenos Aires. El historiador P. Blanco Acevedo relata la acumulación de humillaciones que había hecho explotar el deseo de autonomía política de los vecinos de Montevideo:

Largo había sido el tiempo transcurrido y muchos los factores que intervinieron para llegar a concretarse en esa realidad. Primero los gobernadores y virreyes labraron el surco de las distancias; después, el Consulado con su política, cerrada e inexorable, ahondó y exacerbó las diferencias; la Real Audiencia, con resoluciones notoriamente injustas, hirió y lastimó intereses; el Cabildo virreinal, con sus emulaciones y recelos, tomando para sí toda la gloria en la defensa contra los ingleses; hasta la Iglesia había tenido parte importante en la creación de odiosidades y malquerencias... ${ }^{50}$

Como recuerda el autor del pasaje citado, la actuación de la jerarquía de la Iglesia tuvo una parte de responsabilidad en la ruptura ocurrida entre Montevideo y Buenos Aires. En materia de jurisdicción eclesiástica, la primera estaba subordinada a la segunda desde su fundación. La idiosincrasia de los vecinos fundadores de Montevideo, criollos de tercera o cuarta generación y peninsulares hijos del siglo XVIII, se manifestaba en una religiosidad menos entusiasta que la que se practicaba en ciudades más antiguas de la América española. Una reducida presencia de comunidades religiosas -los Padres de la Compañía habían sido expulsados en 1767 y únicamente los frailes de San Francisco tenían establecido un convento sin rama femenina- entorpeció el surgimiento de vocaciones a la vida monástica entre los hijos de las familias acomodadas de Montevideo. Asimismo, el número de sacerdotes seculares fue siempre exiguo, en consonancia con la población y las

49 Los miembros de la Junta de Gobierno de Montevideo fueron, por el cabildo: los regidores Pascual Parodi, Pedro Francisco Berro, Manuel Ortega, José M. de Ortega, Manuel V. Gutiérrez, Juan Domingo de las Carreras y Juan J. Seco; por el Ejército: los militares Prudencio Murguiondo, Juan Balbín González Vallejo y Diego Ponce de León; por la Iglesia: el Pbro. José Manuel Pérez Castellano y Fr. Francisco Javier Carvallo; por la Administración de Aduana: D. José Prego de Oliver; por el Comercio y los Hacendados: Miguel A. Vilardebó, Francisco A. Suárez, Pedro José de Errazquin, Joaquín de Chopitea, Mateo Gallego. La presidencia del cuerpo correspondió al gobernador, el coronel Francisco Javier de Elío, y los asesores fueron: el Dr. José Eugenio de Elías y el Dr. Lucas José Obes. El secretario y escribano fue D. Pedro Feliciano de Cavia.

50 Blanco Acevedo 1959: 225. características de ésta. En la generalidad de los casos, estos clérigos ubicados entre el siglo XVIII y el XIX, se reconocen más por su formación humanista y científica que por su piedad y celo apostólico, que tampoco les faltaba. ${ }^{51} \mathrm{La}$ ausencia de un prelado local quizá pesó negativamente en el compromiso de los clérigos y en la práctica de la fe entre los montevideanos. En un ambiente de formación religiosa pobre y de una piedad tibia, en un puerto de mar expuesto a los vientos cambiantes del comercio y de la guerra, el deseo de una autonomía en la que se cifraba la felicidad parecía ser la única bandera bajo la que se enrolaban todos.

La solicitud de creación del nuevo obispado debió concebirse en el seno de la Junta de Gobierno entre otras reformasy mejoras concebidas para la ciudad y sujurisdicción. Era el resultado de aquel momento extraordinario en el que podían decidir por sí y ante sí sin otra subordinación más que a la lejana y mediatizada metrópoli. La fundamentación de aquel derecho venía de la tradicional concepción de la monarquía usufructuaria. Decía el Dr. Lucas Obes -asesor de aquella junta- en carta escrita a D. Vicente A. Echeverría, quien se había manifestado contrario a esa corporación de gobierno: «si el pueblo español o la monarquía española reasumió las facultades endosadas al soberano y por esta razón es árbitra de introducir novedades en el gobierno, también lo será la América como parte integrante de ese pueblo, nación, reino o como Vd. quiera llamarle». ${ }^{52}$ Sería mucho pedir a aquellos vecinos constituidos en gobierno emergente, la mayoría de ellos comerciantes y hacendados, reconocer la complejidad jurídica y eclesiástica que imponía el establecimiento de una sede episcopal.

La Junta de Montevideo en su solicitud empleó un lenguaje distinto al utilizado por Suárez en su escrito. El de la corporación es ponderado y florido, si se lo compara con el más directo y en ocasiones inflexible del síndico procurador. No obstante, más allá de la grandilocuencia de algunos giros, el petitorio de la Junta cuida de mencionar los fundamentos en los que creían se podía sostener la solicitada jurisdicción eclesiástica. En uno de los primeros pasajes del escrito aparecen los «sentimientos y clamores de los habitantes de este Pueblo y de toda la circunferencia oriental de esta Vanda del Río de la Plata» que querían ser consolados por la «dulzura del Padre, la sabiduría del Legislador, o el brazo fuerte y poderoso del Soberano». ${ }^{53}$ Entre los considerandos figuraba en primer lugar la deseada concordia y armonía «entre el santuario y el solio por el mayor progreso y exaltación de la Religión y de la santa fe católica». En segundo término y pasando a un plano de mayor realismo político, el escrito de la Junta hablaba de la "Banda Oriental de Montevideo», como del territorio sobre el cual se asentaría el obispado. La ciudad aparece asociada a una jurisdicción geográfica mayor a la que existía legalmente en los hechos, de acuerdo con su intención de expandir los límites hasta alcanzar las fronteras naturales de la región.

51 Basta mencionar entre los orientales a los Pbros. Santiago Figueredo, Dámaso A. Larrañaga, José Manuel Pérez Castellano, y Bartolomé Muñoz (nacido en España), a los que cabría agregar los nacidos en la otra orilla del Plata pero que actuaron en la Banda Oriental, como son los Pbros. Tomás Gomensoro y Valentín Gómez.

52 Pivel Devoto 1963: 7-8 T.

53 AGI Buenos Aires 609, La Junta de Gobierno de Montevideo, Montevideo 11 de febrero de 1809. 
El establecimiento de los límites del nuevo territorio diocesano era un asunto que iba más allá de la jurisdicción eclesiástica, para confundirse con la ventaja política que la Junta esperaba de aquel proyecto. Desde la creación de la Gobernación de Montevideo en 1750, sus límites políticos habían sido restringidos a un pequeño territorio que hacía difícil el sostenimiento de una población que había crecido en número y que se esperaba aumentase más aún. Por fuera de esta demarcación original quedaba la mayor parte de la Banda Norte del Plata, rica en ganados y aguadas, que continuaba bajo la jurisdicción directa de Buenos Aires. ${ }^{54}$ En más de una ocasión, el Cabildo de Montevideo había solicitado de la piedad del rey la ampliación del territorio concedido. En 1784, el virrey Marqués de Loreto colocó bajo la jurisdicción militar del gobierno de Montevideo el puerto de Maldonado y las fortalezas de Santa Teresa y Santa Tecla. En 1788, el mismo virrey extendió la autoridad del gobernador de Montevideo -en calidad de sub delegado de Real Hacienda- hasta los ríos Negro, Uruguay y de la Plata, incluyendo la ciudad de Colonia del Sacramento, el Real de San Carlos, y las poblaciones de Rosario, Víboras, Vacas, Santo Domingo de Soriano, Maldonado, San Carlos, Santa Teresa, y Santa Tecla. Todos estos pueblos dejaron la jurisdicción de Buenos Aires para pasar a la de Montevideo en aquel año. En cambio, en tiempos del virrey Arredondo, el área de mando del gobierno montevideano regresó a sus confines iniciales. El deseo de la Junta de Gobierno en 1808 era ampliar el alcance de sus competencias hasta tocar los límites naturales de la Banda Norte: el río de la Plata y el océano Atlántico por el sur y el este, el río Uruguay por el oeste y la frontera de Portugal (Brasil) por el nordeste. Había un objetivo económico y político detrás de esta iniciativa, hacer converger hacia Montevideo la entera producción de la pradera oriental hasta los límites con el Paraguay y la línea divisoria de Portugal. Montevideo sería así, sin discusión, el puerto principal del Atlántico sur, con la potestad de retener los derechos de aduana de entrada y salida y, al mismo tiempo, ganar un territorio rico y variado. Esta nueva condición y la de constituirse en frontera viva con las tierras de Portugal, exigirían una reorganización política y militar con una mayor autonomía. La creación del obispado de Montevideo cooperaba y perfeccionaba ese ambicioso plan. La pretensión de ampliación territorial con todas sus consecuencias, empero, permaneció incumplida durante el tiempo que todavía restaba al dominio español sobre la Banda Norte del Río de la Plata. ${ }^{55}$

54 Los límites fijados originalmente para Montevideo por Pedro Millán iban: "Desde la boca del arroyo que llaman de Jofré, siguiendo la costa del Río de la Plata hasta este puerto de Montevideo, y desde él siguiendo la costa del mar hasta topar con las sierras de Maldonado, ha de tener de frente este territorio, y por mojón de ella, el cerro que llaman Pan de Azúcar; y de fondo hasta las cabezadas de los ríos San José y Santa Lucía, que van a rematar a un albardón que sirve de camino a los faeneros de corambres, y atraviesa la tierra desde la misma sierra y paraje que llaman Cebollatí, y viene a rematar este dicho albardón a los cerros que llaman Guejonmí, y divide las vertientes de los dichos ríos San José y Santa Lucía a esta parte del sur, y las que corren hacia la parte del norte y componen el río de Yi y corren a los campos del río Negro", en De la Sota 1965: 11-12.

55 En 1811, desde Montevideo, el ex gobernador y antiguo presidente de la Junta de Gobierno, el virrey Francisco Javier de Elio, obtuvo de la Junta de Buenos Aires la firma de un armisticio que llevaba los límites de la jurisdicción de Montevideo a sus fronteras naturales. Este
En el escrito de Bernardo Suárez se establecía que -para la jurisdicción del ordinario diocesano de Buenos Aires- se reservaba «la parte occidental del Río de la Plata», quedando éste con «lo más pingüe del obispado». En tanto, el de Montevideo se erigiría «en su rivera oriental, tomando el río Uruguay por límite y división de los dos obispados». ${ }^{56}$ La nueva diócesis abarcaría -según el síndico procuradorlas ciudades de Montevideo y Colonia del Sacramento y también los siguientes pueblos: «Víboras, Espinillo, Santo Domingo Soriano, Capilla Nueva [la actual Mercedes], Santa Teresa, Rocha, San Carlos y San Fernando de Maldonado».57 No en balde conocía Suárez el territorio gracias a su dilatada colaboración con gobernadores y funcionarios de la Real Hacienda.

El escrito hace, también, una referencia a la corta historia de Montevideo y al progreso creciente de esos últimos años. En opinión de la junta: «bien pudo en sus principios [la ciudad] no merecer toda la atención piadosa y evangelica de los Diocesanos por que la población miserable y diminuta podía ser socorrida fácilmente, pero que aumentada con prodigio, o se abandone o se trate con rigor e indiferencia, y en quanto puede concurrir a la utilidad del Pastor, es un punto muy digno de la reverente representación del síndico Procurador General que dirije esta Junta de Gobierno buscando la protección de V.R. Persona». ${ }^{58}$

Otro fundamento necesario para la implantación de un nuevo obispado era el sostenimiento económico del prelado y de su cabildo. Continúa diciendo el escrito de la Junta, que sería imperdonable no poner los medios para que florecieran «la Religión y el Estado» y se desterrase «la vergonzosa barbarie». ${ }^{59}$ Un medio principalísimo para lograr aquella transformación era: «erigir en obispado esta parte oriental tan basta como opulenta y capaz de proporcionar a los Ministros del Santuario una congrua suficiente a mantener el honor y dignidad sacerdotal». ${ }^{60}$ En el escrito del síndico procurador se aseguraba que los diezmos de la Banda Oriental eran «ya suficientes para q.e. en esta Ciudad tenga su silla con el coro correspondiente al nuevo obispo, sin gravar en nada a la Rl. Hacienda». ${ }^{61}$ Con esta finalidad solicitaba a la Junta de Gobierno: "se sirvan V.S.S. remitir a S.M. informe del valor de los diezmos de esta Ciudad en el último quinquenio y la noticia que se pueda adquirir de lo que en el mismo quinquenio han valido los diezmos

tratado de pacificación entre los dos gobiernos del Plata -el rebelde de Buenos Aires y el de Montevideo que era fiel a la Regencia-, no fue duradero. Nuevamente en 1813, el Jefe de los Orientales, José Artigas, en sus célebres «Instrucciones», retomó el tema de los límites y proclamó que los pueblos «desde la costa oriental del río Uruguay hasta la fortaleza de Santa Teresa forman una sola Provincia», intentando realizar una vez más el sueño de la consolidación territorial.

56 AGI Buenos Aires 609, Bernardo Suárez al Presidente y Vocales de la Junta de Gobierno, Montevideo 7 de febrero de 1809.

57 AGI Buenos Aires 609, Bernardo Suárez al Presidente y Vocales de la Junta de Gobierno, Montevideo 7 de febrero de 1809.

58 AGI Buenos Aires 609, La Junta de Gobierno de Montevideo, Montevideo 11 de febrero de 1809.

59 AGI Buenos Aires 609, La Junta de Gobierno de Montevideo, Montevideo 11 de febrero de 1809.

60 AGI Buenos Aires 609, La Junta de Gobierno de Montevideo, Montevideo 11 de febrero de 1809.

${ }_{61}$ AGI Buenos Aires 609, Bernardo Suárez al Presidente y Vocales de la Junta de Gobierno, Montevideo 7 de febrero de 1809. 
arrendados». ${ }^{62}$ Cuando el asunto llegó a la metrópoli, una de las primeras decisiones adoptadas fue pedir a la Real Hacienda que informase pormenorizadamente sobre la recaudación de los diezmos en cada uno de los pueblos de la diócesis de Buenos Aires.

Si bien no es objeto de este trabajo la consideración de los diezmos que podría haber rendido el nuevo obispado, no por ello debe omitirse algún dato ilustrativo. Antes, debe decirse, que el cálculo de los diezmos es difícilmente realizable por carecer de elementos suficientes. También altera cualquier análisis posible de la cuantía de los diezmos saber que, desde 1776 la diócesis de Buenos Aires estaba repartida en cuatro jurisdicciones, «cuyas iglesias matrices funcionaban como cabeceras de diezmos: Buenos Aires, Montevideo, Corrientes y Santa Fe». ${ }^{63}$ La mayor parte de los diezmos de estas iglesias y sus territorios eran enviados a la capital virreinal; solamente una mínima parte de los diezmos de Montevideo se conservaban en su iglesia. ${ }^{64}$ Tampoco los diezmos de los pueblos que de acuerdo al proyecto de Suárez pasarían al nuevo obispado «se arrendaban en Montevideo sino en Buenos Aires». ${ }^{65}$ Esto quiere decir que el proyecto de obispado de Montevideo hubiese desatado una larga disputa con el de Buenos Aires en caso de prosperar.

Un moderno estudio sobre los diezmos del Río de la Plata afirma lo siguiente: "la masa decimal partiendo de un nivel bastante bajo en 1776 aumenta hasta superar los 100.000 pesos en el primer quinquenio del siglo XIX y luego vuelve a caer». ${ }^{66}$ Si en cambio nos concentramos en una parte de lo que pudo ser el territorio diocesano proyectado, afirmaba el Pbro. José Manuel Pérez Castellano -Juez de Rentas Decimales en Montevideo hacia fines del siglo XVIII-, que del remate de los diezmos de cuatropea -o del ganado- en la Banda de Montevideo, no salían más de mil quinientos pesos. Pérez Castellano alegaba que de cobrarse el diezmo en cueros aumentaría la recaudación a quince o veinte mil pesos. ${ }^{67}$ Es muy probable que en los cálculos de Pérez Castellano no estuvieran considerados algunos pueblos que pertenecían al territorio solicitado para la nueva diócesis. Conforme pasaron los años, la recaudación decimal aumentó con el desarrollo de la producción ganadera y preferentemente con la agrícola. En referencia a la explotación cerealera y más en concreto a la del trigo, la región recostada sobre el río Uruguay no dejó de crecer en los años finales del siglo XVIII y comienzos del XIX. Los diezmos agrícolas de aquellas ricas tierras ubicada al oeste de la Banda Oriental -según un estudio de Gelman-, no tuvieron el papel menor que la historiografía tradicional asignó a este sector de la producción. En aquella zona: «Los montos pagados por los granos representaron, entre

62 Los «diezmos» gravaban la propiedad territorial con la décima parte de los frutos que provenían de los campos, prados, viñas, árboles y animales; originalmente se pagaban en especie pero en América se colectaban en dinero. Existía la posibilidad de que una persona rematara los diezmos de un lugar adelantando la cantidad esperada y encargándose luego de cobrar las cantidades entre los propietarios.

63 Gelman 1992: 46

64 Ídem.

65 Ídem. Los pueblos son: Colonia, Víboras, Espinillo, Santo Domingo Soriano, Santa Teresa, Rocha, San Carlos y Maldonado.

66 Di Stefano 2000: 96 Consultado en: www.biblioteca.unlpam.edu. ar/pubpdf/quisol/n04a05distefano

67 Villegas 2000: 21-24.
1782 y 1802 , un poco más del $40 \%$ del monto pagado por éstos y el ganado en total». ${ }^{68}$ En conclusión, puede ubicarse un pico en la recaudación de diezmos en el Río de la Plata hacia los años 1804 o 1805, lo que podría fundamentar la solicitud elevada por Montevideo pocos años después. Los datos del comercio, por su parte, ratificaban los relativos al ganado y la agricultura. Con esos cálculos pude decirse que la recaudación de los diezmos que se hacía en la jurisdicción de la Banda Oriental -en los primeros años del siglo XIX-, había ido en aumento y posiblemente sufragase una modesta sede episcopal desprovista de todo boato y aún de cabildo propiamente dicho.

En opinión de la Junta, la división del obispado de Buenos Aires ofrecía enormes esperanzas para un más eficaz adelantamiento de la fe y la felicidad pública:

Qué ventajas Señor y que resurrección tan gloriosa! Si el Reverendo Obispo de Buenos Ayres no puede exercer en esta Vanda todo el celo pastoral: si aun quando pudiera, los límites de la capital bastan para ocuparlo dejando pocos momentos al descanso y al reposo: si sus proventos sobran para mantener el explendor del báculo: si por otra parte la Provindencia tiene ya demarcadas las jurisdicciones con el Río de la Plata: sí a proporción de los operarios debe crecer la viña del Señor: esta Junta, su Illmo. Cavildo, el Pueblo, todos piden a V.M. el buen despacho de una solicitud que en nada se parece a la de la Madre de los Cevedeos para ser repulsada. ${ }^{69}$

En este pasaje se condensan las razones suficientes y el apoyo unánime que a juicio de la Junta alcanzaban para justificar la medida solicitada. La referencia inicial al obispo de Buenos Aires hace gala de una sutil ironía; no debe olvidarse que se trataba del mismo prelado de quien se había solicitado antes que fuese removido del cargo. La interesada interpretación que la Junta hace de la división de la diócesis de Buenos Aires la lleva a decir que esa medida beneficiaría al Ilmo. Lué y a sus sucesores; éstos se verían aliviados de la responsabilidad pastoral de la Banda Oriental. La propia geografía parecía aconsejar la separación del obispado, puesto que el río de la Plata y el río Uruguay constituían una barrera natural que no permitía la fácil comunicación entre ambas orillas. Finalmente, se ofrecía la expectativa de que ese cambio lograría aumentar los frutos de la evangelización con nuevos operarios guiados por un pastor cercano y celoso de su grey. La frase final del pasaje citado, de sabor evangélico, pretende desterrar de la opinión del soberano la "falsa» idea de que aquella solicitud fuese desmedida o interesada en castigar al prelado de Buenos Aires.

La solicitud de la Junta debió seguir en la metrópoli el parsimonioso trámite habitual de los expedientes que iban de Indias, con el agravante de la difícil situación política que se vivía en la península y más tarde en el Río de la Plata. La Cámara de Indias pasó con fecha del 14 de mayo de 1810 el expediente a la Contaduría General; ésta, a su vez resolvió, el 11 de septiembre de ese mismo año y en forma previa a toda otra consideración, solicitar informes al virrey del Río de la Plata, Audiencia de Buenos Aires, cabildo secular y metropolitano de Charcas, obispo de Buenos Aires y su

68 Gelman 1992: 46.

69 AGI Buenos Aires 609, La Junta de Gobierno de Montevideo, Montevideo 11 de febrero de 1809. 
cabildo, y finalmente al nuevo gobernador de Montevideo. Al mismo tiempo, se determinó que por parte de los tribunales de Real Hacienda establecidos en la capital virreinal, se realizase y enviase a España un detalle pormenorizado de los diezmos "por un decenio», con distinción "de los valores de cada paraje» de la diócesis. El fiscal del Consejo aprobó lo actuado por la Contaduría con fecha del 26 de junio de 1811 y el expediente fue considerado en Sala de Gobierno por el Consejo. En la resolución de aquel órgano se tuvieron en cuenta las circunstancias derivadas de la revolución de 1810 en Buenos Aires y la generalización de la insurgencia. Así, dos días después, el Consejo aprobó requerir los informes y datos enumerados con la precisión de que aquellas diligencias se hiciesen por los «medios q.e. permitan las circunstancias en q.e. se hallen aquellas Provincias y le dicte su prudencia». ${ }^{70}$ El 12 de julio de 1811, Pedro Telmo Iglesias - del consejo de Ultramar- firmó la carta acordada con destino al virrey del Río de la Plata. Por ese tiempo, la capital virreinal había pasado a Montevideo y el virrey era quien en 1808 y 1809 había presidido su Junta de Gobierno, el general Francisco Javier de Elío. El vértigo de los acontecimientos desde el levantamiento de mayo de 1810 en Buenos Aires y la destitución del virrey Cisneros impondrían una nueva realidad al trámite. La resolución del Consejo llegó finalmente a Montevideo en los primeros días de 1812, cuando ya había desaparecido el virreinato -Elío estaba de regreso en la península- y Montevideo se preparaba a soportar un nuevo sitio de las fuerzas patriotas. En aquellas difíciles circunstancias, la consulta debió ser evacuada por el capitán general del Río de la Plata y gobernador de Montevideo, el mariscal Gaspar de Vigodet, quien no tenía con la ciudad el mismo grado de compromiso que su antecesor. Tampoco era posible satisfacer las diligencias solicitadas por el Consejo de Indias. Vigodet, en consecuencia, se limitó a pedir informes al ayuntamiento de la ciudad y a los ministros «que fueron de la Real Audiencia de Bs. Ayres que hoy se hallan en esa plaza». Al concluir la indagatoria se vio en la necesidad de advertir al secretario del Consejo, que el trabajo se había hecho «arreglándose a las circunstancias en que se hallan estas Provincias que no permiten instruir un expediente en la forma que desea el expresado Consejo». ${ }^{71}$

La pérdida de la capitalidad virreinal por parte de Buenos Aires y el traslado de los altos tribunales a su competidora en el Plata, fue finalmente contraria a los intereses de Montevideo: no fue posible dar satisfacción a la solicitud de la burocracia metropolitana. La imposibilidad de reunir la información solicitada se acumuló a los avatares que la guerra y la revolución dejaron a una y otra orilla del océano Atlántico. No hubo, en adelante, tiempo ni recursos para despachar el expediente con la solicitud de Montevideo. La creación del obispado de Montevideo no estaba reservada para los tiempos del dominio español.

Pasaron algunos años y al darse forma constitucional un nuevo estado sobre Montevideo y su jurisdicción -la

70 AGI Buenos Aires 609, Expediente sobre erección de un nuevo obispado en la Banda Oriental del Río de la Plata y plaza de Montevideo dividiendo en dos el de Buenos Ayres, Cádiz 28 de junio de 1811.

71 AGI Buenos Aires 609, Gaspar de Vigodet al Sor. Secretario del Consejo de Indias Don. Pedro Telmo Iglesias, Montevideo 26 de enero de 1812.
República Oriental del Uruguay-, se dispuso en 1830 que la Iglesia de Montevideo fuese desgajada de la diócesis de Buenos Aires. Se concretaba así la vieja aspiración del patriciado comercial montevideano que -una vez superadas la guerra civil, la revolución y la invasión lusitana- tomaba la dirección de la patria naciente. El 14 de agosto de 1832 fue constituido el Vicariato Apostólico y designado el Pbro. Dámaso A. Larrañaga para ocupar el alto cargo. Pero aún debieron pasar varias décadas para la erección diocesana. Finalmente, el 13 de julio de 1878, el papa León XIII creó el obispado de Montevideo, confirmando a quien hasta ese momento se hallaba al frente del Vicariato del Uruguay, Mons. Jacinto Vera y Durán, consagrado primer obispo de Montevideo. Habían transcurrido casi setenta años desde la primera solicitud de erigir una sede episcopal en la ciudadpuerto al norte del Plata.

\section{LA INSTAURACIÓN DE UNA COlEgIATA EN MONTEVIDEO}

La solicitud de erigir el obispado de Montevideo como medida afianzadora de la autonomía política fue de inmediato seguida de otra iniciativa, lo que puso de manifiesto la decisión con la que la ciudad y sus vecinos perseveraban en el propósito. Se trata del proyecto de erigir la Iglesia Matriz de Montevideo en colegiata. En septiembre de 1810, luego de producida la revolución en Buenos Aires y que Montevideo declarase su fidelidad a la monarquía, los capitulares firmaron un nuevo escrito en el que se pedía proveer el curato de la Matriz en «persona acreedora a la confianza de sus feligreses», al mismo tiempo que se solicitaba que el templo mayor de la ciudad fuese erigido en colegiata. ${ }^{72}$

El desentendimiento con el Pbro. Juan J. Ortiz, Cura Rector de la Matriz, venía de tiempo atrás y estaba relacionado con la oposición del clérigo a la creación de la Junta de Gobierno en 1808 y probablemente a la política practicada por aquel órgano autónomo. De mucha mayor trascendencia en el plano autonómico es la solicitud de una colegiata para la ciudad. ¿Cuál pudo ser la intención con la que el ayuntamiento montevideano hizo esta propuesta? A la vista de las dificultades que presentaba la creación del obispado -el Pbro. Rafael Zufriategui que era el delegado de la ciudad en Cádiz mantendría informados a sus comitentes-, los regidores recurrieron a la figura canónica de la colegiata como medida temporal y sucedánea del obispado. La colegiata es una iglesia principal que, sin tener silla episcopal y en consecuencia no ser catedral, debía incorporar un cabildo eclesiástico con las dignidades y facultades correspondientes. La fundación de una colegiata procedía en aquellos casos en los que sin voluntad de crear una diócesis, el crecimiento de la ciudad o su importancia lo justificaban. Las exigencias de tal fundación eran muy menores frente a las que demandaba la silla episcopal. Ahora bien, debe tenerse en cuenta que -en algunas ocasiones-el cabildo de una colegiata podía administrar el patrimonio local y adoptar decisiones de gobierno, por ejemplo en el caso de vacancia de la sede o en otras circunstancias difíciles. Estas atribuciones eran interesantes a los ojos

72 AGI Buenos Aires 600, el Ayuntamiento de Montevideo, 21 de septiembre de 1810 . 
de los cabildantes y de sus representados. La justificación con la que los montevideanos hacían aquella solicitud era «libertar a aquel fidelísimo pueblo por este medio de la repetición de tan graves disgustos»; éstos eran los que se seguían de tener que obedecer los dictámenes de Buenos Aires. ${ }^{73}$ La ciudad-puerto estaba determinada a alcanzar la emancipación del gobierno eclesiástico al precio que fuere.

Los sucesos ocurridos en mayo de 1810 en Buenos Aires habían puesto al desnudo la fuerza desintegradora de la secesión. En ese momento, para Montevideo -con razón o sin ella- como excusa o motivo de fondo, la dirección hacia la que apuntaba la Junta de Buenos Aires dejaba profundas dudas sobre su fidelidad a la monarquía. En consecuencia, se hacía preciso dotar de autoridad y poder superiores a los funcionarios que estaban en la ciudad todavía leal a la Corona. Esa misma fidelidad pasaba por la reafirmación de la autonomía en la jurisdicción eclesiástica, escapando de la sujeción que la ataba a la antigua capital virreinal. Sin embargo, no se ha encontrado información o respuesta al planteo de crear una colegiata en Montevideo como proponía el ayuntamiento de la ciudad.

\section{CONCLUSIÓN}

Antes que una independencia local-concepto y realidad que la «polis» montevideana no asumió sino quince años después de iniciada la revolución en el Plata como cauce de sus aspiraciones-, fue la autonomía la que interpretó preferentemente los afanes de la ciudad y sus vecinos y lo hizo desde muy temprano, hacia fines del siglo XVIII. Es el deseo vehemente de esa autonomía expresado por la "ciudad-estado» portuaria, lo que permite comprender, además, las decisiones adoptadas por sus representantes en el áspero camino que culminó con la conquista de las libertades. Autonomía que después de finalizado el dominio español se buscó y no fue posible alcanzar bajo el dominio de Portugal -en menor medida era posible esperarla del imperio del Brasil o de las Provincias Unidas del Río de la Plata- que fueron los gobiernos que se sucedieron en el dominio político del territorio oriental hasta que éste conquistó su libertad. ${ }^{74}$

En esta maduración, no fue ajena la constitución de Montevideo como punto de destino del correo que venía de la metrópoli para el hemisferio sur y luego, fundamentalmente, la obtención de la calidad de puerto mayor dispuesta por el Reglamento de Comercio Libre. También hizo sus efectos la experiencia de la ocupación británica de 1807 y la prueba real de autonomía en 1808. Le cupo en suerte a la Junta de Gobierno en 1809, aprovechando la suspensión de los vínculos con el gobierno virreinal al que acusaba de connivencia con el invasor europeo, solicitar la división del obispado de Buenos Aires con la creación de una sede propia en Montevideo.

Era posible esperar que las medidas del gobierno español, adoptadas a la luz del pensamiento ilustrado y de

73 AGl Buenos Aires 600, el Ayuntamiento de Montevideo, 21 de septiembre de 1810 .

74 El territorio de la antigua Banda Norte del Plata o Banda Oriental del Uruguay es el espacio geográfico que aproximadamente ocupa hoy la República Oriental del Uruguay. un liberalismo incipiente, produjesen un exacerbamiento de las apetencias locales de una mayor autonomía. Las bases espirituales y políticas sobre las que se había levantado el edifico del Reino de Indias durante el gobierno de la Casa de Austria, estaban ya minadas en el siglo xVIII y toda la construcción delataba su ruina inminente. Ésta podía apreciarse -particularmente- en la dejación que la Corona hacía de su responsabilidad en América y en la ausencia de creatividad para enfrentar los nuevos tiempos con respuestas inteligentes. Al mismo tiempo, las libertades concedidas para lograr una explotación moderna de las posibilidades que ofrecía la América española en el siglo XVIII -destinadas principalmente a favorecer los intereses de la metrópoli-, no hacían sino alimentar la sed de nuevas y más reales libertades. Es en este escenario que las autoridades de Montevideo demostraron su desagrado ante la gestión de un prelado lejano y ajeno a los intereses de la ciudad. La autonomía en materia de jurisdicción eclesiástica, en el ocaso del mundo antiguo, iba mucho más allá de las manifestaciones de la piedad popular o del cuidado por la suerte eterna de las almas. La Iglesia en América había venido ocupando un lugar destacado en todos los órdenes de la vida desde su llegada al continente, como posiblemente en ningún otro lugar y tiempo lo haya tenido. Por esta razón, el gobierno de Montevideo perseguía esa independencia que le aseguraba un margen de acción importante. En plena lucha por la independencia, el caudillo oriental D. José Artigas planteó en el artículo 3o de sus célebres «Instrucciones», la necesidad de promover "la libertad civil y religiosa en toda su extensión imaginable». ${ }^{75}$ Al decir de algunos estudiosos, el artículo citado consagraba no solo la libertad de cultos, sino también la independencia de la jurisdicción eclesiástica de la provincia. ${ }^{76}$ De seguirse esta interpretación del texto artiguista, se encontraría en la pretensión de autonomía eclesiástica una línea de continuidad entre lo que sostenía el último gobierno español de Montevideo y el que los patriotas se dieron en la emergencia revolucionaria. La lucha por la autonomía fue una causa común en todos los planos y en la que se unirían finalmente todos los bandos: ella representaba el espíritu pujante de la ciudad puerto, que no olvidaba sus raíces pero afirmaba su singularidad. La iniciativa del obispado de Montevideo en 1809 es un episodio ignorado en el análisis de la lucha por la autonomía local. Fue, sin embargo, una de las propuestas más relevantes del período llamado de la Junta de Gobierno, la primera en formarse en la América del Sur a imitación de las establecidas en España.

\section{BiBLIOGRAFÍA}

Andrés, J. 1848. Diccionario de Derecho Canónico. T. III. Madrid: Imprenta de D. José G. de la Peña.

Azcona, J. M. 1989. «El comercio de negros en tiempos de Carlos III (1786)». Letras de Deusto: 79-92.

Blanco Acevedo, P. 1959. El Gobierno Colonial en el Uruguay y los Orígenes de la Nacionalidad. Montevideo: Ligu.

Bruno, C. 1971. Historia de la Iglesia en la Argentina, vol. VII. Buenos Aires: Ed. D. Bosco.

\footnotetext{
75 Miranda 1964: 82

76 Esteva 1993: 22.
} 
De la Sota, J. M. 1965. Historia del Territorio Oriental del Uruguay. Montevideo: Clásicos Uruguayos 73, Barreiro y Ramos.

Di Stefano, R. 2000. «Dinero, poder y religión: el problema de la distribución de los diezmos en la diócesis de Buenos Aires (1776 1820)». Quinto Sol No. 4: 87-115.

Egaña. A. de. 1966. Historia de la Iglesia en la América Española desde el Descubrimiento hasta comienzos del siglo XIX. Hemisferio Sur. BAC 256. Madrid: La Editorial Católica.

Esteva, E. 1993. Lecciones de Derecho Constitucional 2, T. I. Historia Constitucional del Uruguay. Montevideo: Ediciones Revista Uruguaya de Derecho Constitucional y Político.

Falcao Espalter, M. 1926. Entre dos siglos, el Uruguay alrededor de 1800. Montevideo: Agencia Gral. de Librería y Publicaciones.

Gelman, J. 1992. «Producción campesina y estancias en el Río de la Plata colonial: la región de Colonia a fines del siglo XVIII». Boletín del Instituto de Historia Argentina y Americana Dr. E. Ravignani, Tercera serie, No. 6: 41-65.

Mellet, J. 1988. Viajes por el interior de América Meridional. Buenos Aires: Biblioteca Argentina de Historia y Política - Hyspamerica.

Miranda, H. 1964. Las Instrucciones del Año XIII. Montevideo: Clásicos Uruguayos 47, Barreiro y Ramos.
Pérez Castellano, J. M. 1968. Selección de Escritos Crónicas Históricas 1787-1814. Montevideo: Clásicos Uruguayos 130, Barreiro y Ramos.

Pivel Devoto, J. E. 1963. La Junta Montevideana de Gobierno de 1808 Contribución Documental, Apartado de la Revista Histórica, T. XXXIII, Nos. 97-99: 5-533. Montevideo: Museo Histórico Nacional.

Rela, W. 2000. Uruguay cronología histórica documentada, vol. 1. New York: N. Ross Publ.

Rhonheimer, M. 2009. Cristianismo y Laicidad: historia y actualidad de una relación compleja. Madrid: Rialp.

Sala de Tourón, L.; De la Torre, N. y Rodríguez, J. C. 1967. Estructura económico-social de la colonia. Montevideo: Ediciones Pueblos Unidos.

The Southern Star (La Estrella del Sur), Saturday May 23, 1807, No. 1 (facsímil): 1. Montevideo: Instituto Histórico y Geográfico del Uruguay - Barreiro y Ramos.

Villegas, J. 2000. «Memorial del Pbro. José Manuel Pérez Castellano sobre asunto de diezmos en la jurisdicción de Montevideo», en Documentos para la historia de la Iglesia en la Banda Oriental: 1-47. Montevideo: CEHA. 